\title{
ENHANCING STUDENTS' METACOGNITION IN THE CLASSROOM
}

\author{
Anda Priedite \\ University of Latvia
}

\begin{abstract}
Metacognition and its effects on learning have been studied for more than 40 years. However, until now there has not been a requirement for teachers in Latvia to develop students' metacognitive skills. With the new competence-based curriculum from $1^{\text {st }}$ September 2020, it will become mandatory. Three essential regulation skills that student's need to develop are planning, monitoring and evaluating.

To understand better teachers' current practice and readiness to implement new curriculum, a case study was carried out. The aim of the case study was to collect data about elements of metacognition in teachers' current practice. To achieve this aim, 20 consecutive lessons were observed in a large school in Riga. Lessons were taught by 10 different teachers, but to the same students ( $10^{\text {th }}$ grade). During the lessons, observations of students and teachers' actions that potentially are connected to the metacognition were recorded and briefly described. Afterwards field notes were classified and analysed according to the categories planning, monitoring, evaluating. In conclusion, practical ideas to promote students' metacognition are summarised.
\end{abstract}

Keywords: metacognition, teachers' practice, planning, monitoring, evaluating.

\section{Introduction \& background}

In the literature, metacognition was first described in the late seventies of $20^{\text {th }}$ century by Flavell (1979) as one's knowledge of one's own cognitive processes and anything related to these. In another words, cognitive knowledge and skills are necessary to perform a task, while metacognition is necessary to understand how the task was performed (Garner, 1987, as cited in Schraw, 1998).

Researchers describe two aspects of metacognition - knowledge of cognition and regulation of cognition (Schraw, 1998). This means that metacognition involves not only the knowledge and awareness of cognition but also the ability to control it (Swartz \& Perkins, 1989). In the school context, components of metacognition are awareness of processes that influence learning and the successful completion of the task, ability to 
determine if a task is being completed correctly, capability to monitor progress, adapt and make appropriate changes in learning strategies if necessary (Baker \& Brown, 1984).

Metacognitive knowledge includes declarative knowledge (the students' knowledge of his or herself as a learner, the knowledge about academic tasks), procedural knowledge (the knowledge about learning and learning strategies that can be employed to fulfil the assigned task) and conditional knowledge (knowing when, how and why to use declarative and procedural knowledge) (Baker \& Brown, 1984; Schraw, 1998).

Cognitive regulation skills that students need to advance to become metacognitive and independent learners include self-awareness, selfresponsibility, self-reflection, goal setting, time management, planning and selecting appropriate learning strategies, monitoring progress of learning, analysing the effectiveness of learning strategies, correcting errors and changing learning behaviours and strategies when necessary (Ridley et al., 1992; Winn \& Snyder, 1996).

In the next few years, the gradual transition to competence-based education will take place in schools of Latvia. Previous amendments to the basic education standard were made in 2014. The new basic education standard comes into force on September $1^{\text {st }}, 2019$. One of the major changes in the new standard is that in addition to subject specific knowledge, skills and competences content has been complemented by transversal skills and value-based habits (Regulations Regarding the State Standard in Basic Education, $\mathrm{LV}, 2018)$. Metacognitive skills are incorporated under one of six transversal skills related to self-regulated learning. Despite the fact there are common core between self-regulated learning and metacognition, they cannot be viewed as synonyms. Self-regulated learning incorporates aspects of both metacognition and self-regulation (Dinsmore, Alexander \& Loughlin, 2008). The focus of this article is metacognitive part of self-regulated learning.

Among the new basic education requirements, metacognitive learning outcomes are:

- Students set short-term and long-term goals, plan steps to achieve the goal,

- Students use the strengths of their thinking and strategies of thinking that are appropriate to the situation to develop their abilities and improve their performance,

- Students independently develop criteria, which indicate the achievement of the goal, learn about their progress and determine whether and how to improve performance.

- Students use mistakes to purposefully change their actions. In the course of learning, students re-plan a few steps to get a better solution. 
The implementation of the new standard in schools will begin as of September 1, 2020 for grades 1, 4 and 7, on September 1, 2021 for grades 2, 5 and 8, and September 1, 2022 for grades 3, 6 and 9. To implement metacognition in practice, teachers will need support. In the next sections of the article, the general principles that characterize classroom practice promoting metacognition are outlined and case study results (that was carried out in a school that represents a typical large school in Riga) are analyzed to better understand teachers' current practice. In conclusion, the findings about the students and teacher actions that enhance students' metacognitive skills are summarised.

\section{Metacognition in classroom}

There are many evidences provided by researchers as to why metacognition is important in learning process and why teachers should focus their attention on the development of students' metacognitive skills. For example, Alexander and colleagues (1988) suggest that teaching metacognitive strategies improves students' academic achievements, by improving students' cognitive processing and learning (Azevedo, et al. 2007). Teaching metacognitive strategies also increases students' selfawareness about what it takes to learn (Kolencik \& Hillwig, 2011). In fact, in some situations metacognitive knowledge and cognitive regulation skills can compensate for the lack of cognitive knowledge and skills (Schraw, 1998).

Costa (1984) points out that in the learning process students tend to follow instructions and rarely think about learning strategies and efficiency of their learning, if they are not encouraged by the teacher. To develop students' metacognitive skills and the habit to use those skills it is necessary to include in lessons activities/ tasks/, methods that compel students to think about their thinking and learning process. However, this should not be seen as some additional activities and tasks for teachers to do, but rather as effective pedagogy that is incorporated in their everyday classroom practice (Quigley, et al., 2018).

There are various strategies to enhance metacognition for teachers to choose. In previous research that aims to identify instructional approaches that promote metacognition, three categories of instructional strategies have been identified - planning, monitoring and evaluating thinking (Ellis, et al., 2014).

Planning includes goal setting, selection of appropriate learning strategies, estimation of time and resources needed to fulfil the task. Monitoring includes following the fulfilment of the task, ability to engage in periodic self-testing, changing learning strategy if necessary. Evaluating 
includes assessing not only the learning outcome but also the learning process (Quigley, 2016; Schraw, 1998).

In Table 1, questions of self-reflection regarding planning, monitoring and evaluating are summarised. Questions can be used to help students successfully plan, monitor and evaluate the task and their efforts (Quigley, 2016).

Table 1. Questions of self-reflection

\begin{tabular}{|l|l|}
\hline Planning & What prior knowledge do I need to tackle the task? \\
& What type of planning process should I use? \\
What is the most appropriate strategy to fulfil the task? \\
What examples can I use to guide me? \\
How much time do I have? \\
What resources do I need? \\
Where should I start?
\end{tabular}

The Plan, monitor, evaluate cycle can be done over shorter or longer learning activities - it may be one task, one lesson or the whole day. While there are some benefits to introducing students to the planning, monitoring, and evaluating in general, and many of the strategies can be used in different subjects, the evidence suggests that they are best taught through subject content (Quigley, et al, 2018).

Studies also show that direct instructions in metacognition may not be effective. Instead, for metacognition to improve, students have to experience the need for those strategies (Costa, 1984), and that happens when students are challenged. If students undertake a challenging task, they have to develop new skills/ strategies to fulfil it, they have to plan how to overcome challenges and afterwards they have something to reflect on. However, challenges need to be set at an appropriate level, or the learners may not accept the challenge or they can be subjected to cognitive overload (Quigley, et al., 2018). That means that teachers need 
to be careful about when and how to place metacognitive tasks so as not to distract students when they are learning cognitive content because there is a risk that students will not be able to develop new cognitive and new metacognitive skills at the same time (Quigley, et al., 2018).

\section{Methodology}

This article deals with part of the ethnographic research, which aims to develop a support system that would help teachers in Latvia to implement metacognition into their practices. To understand teachers' current practice better, a case study was carried out. The aim of the study was to collect data about the elements of metacognition already present in lessons before the implementation of the new curriculum. To achieve this aim, 20 consecutive lessons taught by different teachers, but to same students ( $10^{\text {th }}$ Form), were observed in a large school (1300 students, 100 teachers) in Riga. The school and the class were chosen randomly. Teachers, students and parents were informed about the study. They were informed that the aim of the study is to better understand the current learning process at the school, but it wasn't revealed that the researcher is particularly interested in metacognition. Participants agreed that data from lesson observation will be analysed. The participants were informed that the name of the school and the names of the teachers and pupils will stay anonymous.

When interpreting the results of this study one needs to remember that it represents situation in a particular school, but as the school chosen for research represents a typical large school in Riga (regarding qualification of teachers, teachers' professional development activities in school, students' results in state examinations and students' background), with caution the conclusions may be extended to other schools.

All lessons the particular students had during the period of three days were observed. The number of lessons was chosen to cover different classes (Latvian, literature, English, German, Russian, history, mathematics, physics, biology, geography, economics) and 10 different teachers. During lesson observations, students and teachers' actions that potentially are connected to the metacognition were recorded and briefly described (teachers' role, students' role, and activities). Afterwards, 19 pages of recorded field notes were classified according to the categories offered in the literature planning, monitoring, evaluating. Only those activities and actions that were purposefully included in the course of the lesson (where the task given by the teacher required students' metacognitive thinking) were used in the analysis. For example, "the teacher asks students to discuss, compare and evaluate their solution of the problem" is a metacognitive activity that is purposely included in the lesson by the teacher, but "during the time that 
teacher is intended for students to work independently on the problem, one student quietly asked his peers to compare results" is not an action that is fostered by the teacher although the student displayed metacognitive monitoring.

\section{Results and discussion}

\section{Planning}

The first step to students' awareness of learning and metacognition is clear learning objectives. Communication of learning objectives was observed in 15 lessons out of 20. Learning objective should state what students would be able to do at the end of the lesson or learning segment. Lesson observation indicates that teachers tend to formulate learning objectives as the theme of lesson, e.g., "Today we will learn about gravitation and motion in gravitational field" or state what students will do in the lesson, e.g., "We will prepare for the test". Another example seen in lessons is to formulate learning objectives as a question, e.g., "Why Charles the Great is important and unique in European history?" A simple way to influence metacognition is to change the way teachers are formulating learning objectives. Verbs like analyse, compare, evaluate, categorise, organise, debate suggests higher level thinking and triggers metacognition by stimulating students to think about what they had to do in the past when they previously had to analyse/ compare/ evaluate etc. (Kolencik \& Hillwig, 2011). In the example about Charles the Great, the improved learning objective would be analyse the influence of Charles the Great on the economic, political and cultural development of Europe.

Only in one lesson (out of 20), the teacher talked not only about learning objectives for specific lesson, but also about the long term learning goals and how the lesson leads to them.

Of concern in this respect, is that students were never involved in the formulation of learning objectives or discussion about them. One of the metacognitive skills students need to develop is setting learning objectives for themselves.

In all of the observed lessons, previously learned knowledge and skills were activated. Activating prior knowledge itself is a metacognitive activity. In almost all cases, teachers used the same method - frontal questions and answers, e.g., "What do you remember from the last lesson?", "What do you know about ...?" "Based on... what we will learn today?" etc. While these are good questions, which stimulate metacognition, rarely more than a few students were actively participated in these question and answer sessions. This can be easily improved by using the think - pair - share technique that was observed in one of the lessons. That would give students a chance to think independently at first, and for all students to be active participants. 
Another approach observed in lessons to activate previously learned knowledge was the use of picture as a way to create initial interest in the content to be studied, and test questions and puzzles as formative assessment of previously learned content. The literature suggests many other ways to activate prior knowledge, e.g., a commonly used organiser is the K-W-L chart (What do I already know? What do I want to learn? What have I learned?) (Kolencik \& Hillwig, 2011). Teachers should be encouraged to be more diverse in methods, techniques and the learning strategies they use in classroom.

Another of the metacognitive skills students should master is the ability to estimate time and resources needed to fulfil the task. Only one of the observed teachers asked students to estimate how much time they will need for a specific task. In two other cases teachers set time limits for activities. However, in all the rest of the observed lessons there were not set any time limits for students and, in combination with vague learning objectives, this discourages students to take responsibility for their time management.

\section{Monitoring}

Regarding monitoring, there were occasions when the teacher stopped students in the middle of the process of problem-solving to discuss their progress. In 10 cases, it happened in response to students' questions, for example, in the lesson of mathematics the question about how to draw specific graphs triggered class discussion. Similar examples were observed, e.g., in the lessons of geography and Latvian. Monitoring was also observed in the situations when students needed to complete tasks with several similar examples (13 cases), e.g., in Latvian students needed to create adverbs from given words. After students tried some examples on their own, the teacher stopped them, compared and discussed what students had written. Then students continued to work on their own.

Another way how monitoring was present in the classroom was in the form of individual feedback from teachers. In some cases, the feedback was given publicly during class discussion (observed in 5 lessons). For example, in the English lesson after each student had presented his/ her arguments, the teacher asked questions, such as "What do you mean with ...?", "Why ...?", "How do you define...?" etc. Similar examples were also observed in lessons of German, history and literature.

The observation showed that a typical way for the teacher to give feedback (observed in 15 lesson) was while students individually worked on the task, the teacher walked through class and gave an individual feedback to students. Mostly this feedback was about cognitive content. However, in some cases there were also metacognitive questions present, e.g., in 
a history lesson the task for students was to display written information on the map. While giving individual feedback, the teacher asked questions like "What was the task?", "Why did you mark this?", "What does this colour/ arrow represents?" etc.

\section{Evaluating}

There were several ways observed in lessons that showed how the teacher encourages students to evaluate their work and learning. One way is to offer students the task of self-reflection at the end of the lesson (observed in 7 lessons). For example, at the end of the Latvian lesson students were asked to complete a short test to check their understanding about adverbs and write questions about what is still unclear for them. At the end of the history lesson students were asked to write three words that describes Charles the Great. At the end of the literature lesson, students were asked to vote about the learning that had happened in the lesson ("Did I learn something new?" "Did I actualise something I already knew?"). At the end of the English lesson, the teacher had a discussion about the debates that students had during lesson, each student was asked, "What do you think you need to improve?", "How did you feel?", "Are you satisfied with your response?"

In one of the observed lessons, self-reflection was the first task students did. In the lesson of economics, students were asked to evaluate what they have already done regarding the idea about their student enterprise.

There were four lessons were teacher intended to offer self-reflective tasks at the end of the lesson, but due to lack of time, it was not properly executed. For example, there were eight lessons where students did not have the time and opportunity to self-reflect about the outcomes of the lesson.

Another way of evaluation observed in lessons was evaluation of particular task that students had worked on (observed in 18 lessons). For example, in the lesson of Latvian, after students had finished a task intended to actualise previous knowledge, teacher had a class discussion about questions like "What part was the easiest? Why?", "What part was the hardest?", "How did you solve the task?" Another example was observed in the German language lesson, where the teacher discussed with students the correct answers, asked students to explain their answers and referred to the diagrams that previously were introduced to better understand grammatical structures. Similar evaluation of task was also observed in other lessons, e.g., mathematics, geography, biology etc. In mathematics, the teacher discussed with students how a particular task would be evaluated in assessment.

Part of evaluation that was not fully utilised in the lessons is peer tutoring and peer evaluation. Although in some of the lessons there were elements of peer evaluation and tutoring recorded, structured example 
of peer evaluation were observed only in one lesson. In the lesson of economics, students were asked to give specific feedback regarding peers' presentations, in the following lesson students worked with the feedback they had received.

\section{Conclusions}

Although the fact that elements of metacognition are present in lessons is encouraging, lesson observations showed that in most cases these activities happen through the teacher. The teacher is mainly the one who states what and how students will learn, what strategies students will use (e.g., what graphic organisers students will use while working with text).

For teachers to implement metacognition into their practice, examples of manageable actions that can be used as first steps in changing their practice and improving students' metacognition could be useful. Based on the data collected in the case study and suggestions from the literature, recommendations to promote students' metacognition are summarised in Tables 2, 3 and 4 .

The first part of each table gives examples of teacher's actions that stimulate students' metacognition. For example, the teacher should verbalise the thinking process regarding the task. By doing so, the teacher shows students how expert thinks about the problem; how the expert approaches and monitors the progress and also, how the expert evaluates the results. When describing their thinking, the teacher should use specific cognitive terminology. By deliberately including metacognitive terms (predict, reflect, classify, hypothesise, justify etc.) teacher demonstrates metacognitive awareness that students should develop (Kolencik \& Hillwig, 2011).

The second part of each table gives examples of students' actions that indicate that students actively think about their learning. Students should first have the opportunity to use the models frequently, but the goal is to start practising these behaviours on their own (Gray, 1991).

The last part of each table gives examples of useful classroom activities/ tasks that teachers can use in their lessons.

Table 2, summarises students' and teacher's actions that enhance metacognitive planning skills. If the recommendations from Table 2 are compared to the case study results, the first step for teachers to improve their practice could be involving students in the formulation of learning objectives. This is also one of the learning outcomes of self-regulating learning in the new basic education standard. Another important aspect regarding planning is that students should be able to choose an appropriate learning strategy for the task. That means that students have to know the different learning strategies (e.g., different strategies of how to work 
with text). In the observed lessons, there was only one occasion when the teacher deliberately taught learning strategy (during the history lesson, teacher demonstrated how to use the graphic organiser to construct a definition of the term). Researches, e.g., Kolencik and Hillwig (2011), indicate that teachers rarely teach learning strategies because they are convinced that students already know and are able to use them. If possible, students should create strategies on their own, discuss and evaluate them and practice them until they become a habit (Costa, 1984).

Table 2. Summary of students' and teacher's actions to enhance planning skills

\begin{tabular}{|l|l|}
\hline Teacher's & $\begin{array}{l}\text { Focus students' attention on learning objectives, short-term and long- } \\
\text { term goals. Make certain that students understand learning objectives. } \\
\text { Activate prior knowledge and skills that will be important during } \\
\text { the lesson/ task. } \\
\text { Verbalise your metacognitive thinking related to planning. } \\
\text { Give an exact and clear instructions for cognitive/ metacognitive } \\
\text { strategies that students will need to use (for example, how to use } \\
\text { a specific graphic organiser), make sure students understand the key } \\
\text { aspects and main purpose of those strategies. } \\
\text { Set time limits for activities. }\end{array}$ \\
\hline $\begin{array}{l}\text { Students' } \\
\text { actions }\end{array}$ & $\begin{array}{l}\text { Set learning objectives for themselves } \\
\text { Conclude what knowledge and skills that they already have are relevant } \\
\text { to the task, and identify what they need to learn. } \\
\text { Select appropriate strategies to fulfil the task successfully. } \\
\text { Consider how to allocate their efforts, split responsibilities. } \\
\text { Assess the time it will take to complete the activity. } \\
\text { Make a list of resources that they will need, and where they can find } \\
\text { them. }\end{array}$ \\
\hline $\begin{array}{l}\text { Examples } \\
\text { of useful } \\
\text { classroom } \\
\text { activities }\end{array}$ & $\begin{array}{l}\text { Together with students, generate a list of questions or things that they } \\
\text { need to learn to solve the problem/ complete the task. } \\
\text { Ask students to rewrite the problem in their own words, identify what } \\
\text { they know and what they need to find out. } \\
\text { Ask students in small groups or pairs, to come up with various ways to } \\
\text { solve the problem/ complete the task. } \\
\text { Use structured planning templates. } \\
\text { Use metacognitive talk/ teacher and student "think aloud". } \\
\text { Visualise planning by using graphic organisers, concept maps, flow } \\
\text { charts etc. } \\
\text { Purposefully teach different learning strategies, e.g., how to take notes } \\
\text { from the textbook. }\end{array}$ \\
\hline
\end{tabular}

Table 3, summarises students' and teacher's actions that enhances metacognitive monitoring skills. If divided in the categories of planning, monitoring and evaluating, most of recorded actions and activities observed in lessons were regarding evaluation, with the least regarding monitoring. There are researches showing that monitoring ability develops slowly and is deficient in children and even adults (Schraw, 1998). That means that monitoring should be of particular interest for future research. 
Lesson observations showed that all elements of monitoring observed in lessons were carried out through teachers' feedback. It can be changed by using peer tutoring or by using checklists and rubrics to enable students to monitor their progress individually.

Table 3. Summary of students' and teacher's actions to enhance monitoring skills

\begin{tabular}{|l|l|}
\hline Teacher's & \begin{tabular}{l} 
During the lesson, refocus students' attention to learning \\
objectives. \\
Break down the activity into simpler steps. \\
Set guidelines/ steps to follow during activity. \\
Verbalise your metacognitive thinking related to monitoring. \\
Teach strategies how to organise and retain information. \\
Use visual timers. \\
Give non-judgemental feedback about students' decisions. \\
$\begin{array}{l}\text { Highlight successful examples and steps that led to success. } \\
\text { Use, paraphrase, extend and build upon students' ideas. } \\
\text { Ask clarifying questions about students' terminology and problem } \\
\text { solving process. } \\
\text { Label students' cognitive processes, e.g., "What you are doing is } \\
\text { called an experiment". }\end{array}$ \\
\hline Students' \\
actions
\end{tabular}$\quad \begin{array}{l}\text { Share their progress, describe their thinking, what they plan to do } \\
\text { next and why. } \\
\text { Use guidelines/ checklists (teacher given or self-made) to monitor } \\
\text { their progress } \\
\text { Examine their errors to identify where and why they went wrong. }\end{array}$ \\
\hline $\begin{array}{l}\text { Examples } \\
\text { of useful } \\
\text { classroom } \\
\text { activities }\end{array}$ & $\begin{array}{l}\text { Use metacognitive talk/ teacher and student "think aloud". } \\
\text { Offer completed or half-done examples, ask to analyse them, then } \\
\text { discuss conclusions. } \\
\text { Provide students with answer sheets after they have tried to solve } \\
\text { the problem. } \\
\text { Ask students to find, correct and explain their mistakes. } \\
\text { Add metacognitive questionnaire for students to complete during } \\
\text { learning activity/ assignment. } \\
\text { Ask students to write down questions / important concepts during } \\
\text { activity. } \\
\text { Invite students to use visual organisers - mind maps etc., to show } \\
\text { and monitor their thinking } \\
\text { Use role play and simulations. } \\
\text { Ask students to solve problems in pairs or small groups, during } \\
\text { activity partners should take turns acting as solver and listener. } \\
\text { Purposefully teach different learning strategies, e.g., triplicate note } \\
\text { making. } \\
\text { Encourage students to give and receive feedback from peers } \\
\text { through gallery critique. }\end{array}$ \\
\hline
\end{tabular}

Table 4, summarizes students' and teacher's actions that enhances metacognitive evaluation skills. Lesson observations showed that in many cases self-reflective tasks at the end of activity or lesson were only about learning outcomes. To develop evaluation skills teachers and students 
should focus more on the process of learning than the results of learning. Creating together with students, check-lists or rubrics, is an effective way to involve students in thinking about the quality of the work.

Table 4. Summary of student and teacher actions to enhance metacognitive evaluation skills

\begin{tabular}{|l|l|}
\hline $\begin{array}{l}\text { Teacher's } \\
\text { actions }\end{array}$ & $\begin{array}{l}\text { Verbalise your metacognitive thinking related to evaluation. } \\
\text { Before learning activity, discuss with students how they will } \\
\text { know that they have completed the task successfully. } \\
\text { Before assignment provide or create together with students } \\
\text { checklists, rating scales or rubrics. } \\
\text { Give feedback according to previously set checklists/ rubrics. } \\
\text { Help students to recognise what they did well and take credit for } \\
\text { it. } \\
\text { Encourage students to seek feedback from their peers. }\end{array}$ \\
\hline $\begin{array}{l}\text { Students' } \\
\text { actions }\end{array}$ & $\begin{array}{l}\text { Evaluate their work and actions according to criteria, use criteria } \\
\text { to justify their reasoning, } \\
\text { Recognise what they did well, and take credit for it. } \\
\text { Seek feedback from the teacher and peers. }\end{array}$ \\
\hline $\begin{array}{l}\text { Examples } \\
\text { of useful } \\
\text { classroom } \\
\text { activities }\end{array}$ & $\begin{array}{l}\text { Use metacognitive questionnaire during an exam/ exam } \\
\text { wrappers. } \\
\text { Ask students to review and analyse individual assessment results } \\
\text { together with metacognitive questionnaire. } \\
\text { Ask students to evaluate and compare multiple examples, with } \\
\text { subtle differences. } \\
\text { Use metacognitive talk/ teacher and student "think aloud". } \\
\text { Encourage peer tutoring (with clear parameters of time, roles and } \\
\text { steps). } \\
\text { Use different methods to give feedback, e.g., "Live feedback". } \\
\text { Offer students opportunities for self-testing and answer checking } \\
\text { Provide students with different methods of self-reflection, e.g., } \\
\text { "Learning journals", "The Week in Review", "Muddiest Point" etc. }\end{array}$ \\
\hline
\end{tabular}

The case study shows that critical aspect of teachers' current practice is the fact that mostly planning, monitoring and evaluating is happening through the teacher. To enhance students' metacognition effectively, teachers should refocus those activities from themselves to students giving students a chance to be more proactive participants in the planning, monitoring and in the evaluating of their learning. This brings questions for future research: what are the factors that prevent teachers from transferring more responsibility to students? How it is connected with teachers' own notion, believes and experience regarding metacognition and self-regulated learning?

100 schools in Latvia now are in the process of piloting new national curriculum, in those schools situation could be different. Research on the experience of piloting schools would be necessary to understand better 
the challenges to implement metacognition and self-regulated learning in the classroom.

\section{References}

Alexander, P. A., Graham, S. \& Harris, K. R. (1998). A Perspective on Strategy Research: Progress and Prospects. Educational Psychology Review, 10, 129-154. https://doi. org/10.1023/A:1022185502996.

Azevedo, R., Greene, J., A. \& Moos, D. C. (2007). The Effect of a Human Agent's External Regulation Upon College Students' Hypermedia Learning. Metacognition and Learning, 2(2), 67-87. DOI: 10.1007/s11409-007-9014-9.

Baker, L., \& Brown, A. (1984). Metacognitive skills and reading. The Handbook of Reading Research. 353-394. New York: Longman.

Costa, A. (1984). Mediating the Metacognitive. Educational Leadership, 42, 57-62. Retrieved March 19, 2019, from http://www.ascd.org/ASCD/pdf/journals/ed_lead/ el_198411_costa.pdf.

Dinsmore, D. L., Alexander, P. A. \& Loughlin, S. M. (2008). Focusing the Conceptual Lens on Metacognition, Self-regulation, and Self-regulated Learning. Educational Psychology Review, 20, 391-409. https://doi.org/10.1007/s10648-008-9083-6.

Ellis, A. K., Denton, D. W. \& Bond J. B. (2014). An Analysis of Research on Metacognitive Teaching Strategies. Procedia - Social and Behavioral Sciences, 116, 4015-4024, https:// doi.org/10.1016/j.sbspro.2014.01.883.

Flavell, J. H. (1979). Metacognition and Cognitive Monitoring: A New Area of Cognitivedevelopmental Inquiry. American Psychologist, 34, 906-911. Retrieved April 25, 2019, from https://pdfs.semanticscholar.org/ee65/2f0f63ed5b0cfe0af4cb4ea76b2ecf790c8d.pdf.

Garner, R. (1987). Cognition and Literacy. Metacognition and Reading Comprehension. Westport, CT, US: Ablex Publishing.

Kolencik, P. L. \& Hillwig. S. A (2011). Encouraging Metacognition: Supporting Learners Through Metacognitive Teaching Strategies. New York: Peter Lang Publishing, Inc.

Quigley, A. (2016). The confident teacher: Developing Successful Habits of Mind, Body and Pedagogy (pp. 220-239). New York: Routledge. ISBN 978-1-138-83234-3.

Quigley, A., Muijs, D. \& Stringer, E. (2018). Metacognition and Self-regulated Learning. Guidance report. Education Endowment Foundation, London, 1-30.

Ridley, D. S., Schutz, P. A., Glanz, R. S., \& Weinstein, C. E. (1992). Self-regulated Learning: The Interactive Influence of Metacognitive Awareness and Goal-setting. Journal of Experimental Education, 60(4), 293-306.

Schraw, G. (1998). Promoting General Metacognitive Awareness. Instructional Science, 26, 113-125, Kluwer Academic Publishers, https://doi.org/10.1023/A:1003044231033.

Swartz, R. J. \& Perkins, D. N. (1989). Teaching Thinking: Issues and Approaches. Pacific Grove, CA: Midwest Publication.

Winn, W., \& Snyder D. (1996). Cognitive Perspectives in Psychology, The Handbook of Research for Educational Communications and Technology. New York: Simon \& Schuster Macmillan, 112-142. 